\title{
非等速ロール間における粉体圧縮モデルの提案
}

\author{
草野 巧巳*，谷 昌明，奥田 勝治，中村 浩
}

\section{Modeling of Differential Speed Rolling of Powder}

\author{
Takumi Kusano*, Masaaki Tani, Katsuharu Okuda and Hiroshi Nakamura
}

Received 1 April 2021; Accepted 21 June 2021

\begin{abstract}
When powder is compacted by a differential speed rolling, the roll speed ratio of the two rolls greatly affects the structure of the compacted product. However, the effect of the roll speed ratio on the structure of the compacted product has not been calculated. In this paper, for compaction process with a differential speed rolling, the weight of the compacted product per unit area was calculated by using a modified Johanson model assuming the velocity gradient of powders, and the calculated values were compared with experimental results. As a result, both the calculated and measured weight of the compacted product decreased as the roll speed ratio increased and the roll gap decreased. It was confirmed that the roll speed ratio dependence and the roll gap dependence of the weight calculated by a modified Johanson model showed the similar trend as those of the experimental results.
\end{abstract}

Keywords: Roll compaction, Powder, Nip angle, Angle of internal friction, Johanson model.

\section{1. 緒言}

ロール圧縮プロセスは金属のシート成形や錠剤成形な ど，さまざまな製造分野で使用されている[1,2]。ロール 圧縮は, 粉体を 2 本のロールで圧縮することにより, シー ト状成形体やタブレットなどの連続体へと成形するプロ セスである。この時，製品の品質を安定にするために成 形体密度や圧縮応力を予想することは重要であり，等速 ロール条件（Fig. 1）での成形体密度や圧縮応力が Johanson モデルにより計算されている[3]。このモデル では，まず，ロール壁面と粉体で滑りが生じる「Slip region」と, 滑りが生じない「Nip region」があると仮定 し，これらの領域が入れ替わる角度を「Nip angle」と定 義される。そして，この考えの元にロールに加わる応力 を計算しており，ロール上の応力分布が実測值と一致す ることも確認されている[4]。

Johanson モデルでは, 粉体の噛み込み方向に粉体の流 れを 1 次元的に計算しているが，実際はロール側で粉体 が速く動き，ロール間のギャップ中央部では粉体の流れ が遅くなると考えられる。実際, DEM シミュレーション やFEM シミュレーションによりロール表面近傍とロー ル間のギャップ中央部で粉体の速度に差があることがわ

\footnotetext{
豊田中央研究所

( T 480-1192 愛知県長久手市横道 41-1)

TOYOTA CENTRAL R\&D LABS., INC.

(41-1 Yokomichi, Nagakute, Aichi 480-1192, Japan)

* Corresponding Author kusano@mosk.tytlabs.co.jp
}

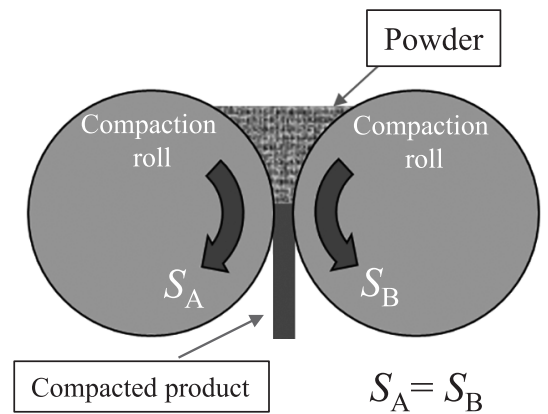

Fig. 1 Schematic illustration of two-roll press

かっており, Johanson モデルで求まる質量流量は実測值 と異なることがわかっている $[5,6]$ 。そのため, 質量流量 の見積もりを行う際には, Johanson モデルよりも FEM シミュレーションが適していると考えられる[6]。しか し, Johanson モデルの Nip angle は妥当であること, シ ミュレーションよりもパラメータが少なく計算が容易で あることから，プロセス条件と成形体構造（重量）との 関係を理解するためには有効なモデルである[4,7]。

一方，粉体プロセスではロールミルなど，速度の異な るロールで粉体を圧縮するプロセス（非等速ロールプロ セス）も重要である $[8]$ 。非等速ロールプロセスにおいて も，等速ロールプロセスと同様にプロセス条件と成形体 重量との関係を明らかにすることは重要であるが，上記 の Johanson モデルでは等速ロールを仮定しているため, ロール速度差の影響を考慮していない。そこで本論文で 


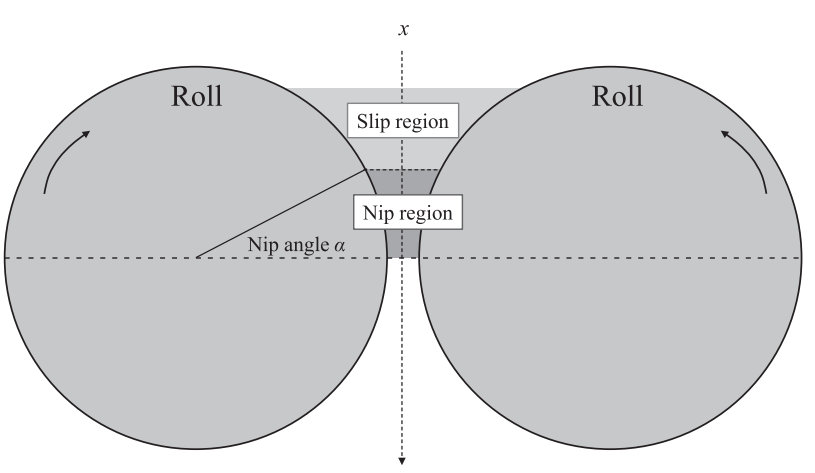

Fig. 2 Definition of nip angle $\alpha$ under two-roll compaction

は，速度勾配を考慮して補正した Johanson モデルを提案 し, 成形体重量の実測值との比較を行うことでその妥当 性を評価した。

\section{2. 圧縮成形体重量の計算}

等速ロール間へ噛み込まれる粉体の体積, 応力計算は すでにJohanson により報告されている[3]。この Johanson モデルでは，まずロール壁面と粉体で滑りが生じる「Slip region」と滑りが生じない「Nip region」があると仮定し, この二つの領域が入れ替わる角度を「Nip angle」と定義 している（Fig. 2)。この時, 応力はロール間ギャップ中 心軸（Fig. 2 の 軸）での応力のみを計算しており，一 次元モデルとなる。また, 応力は時間には依存せず位置 $x$ のみに依存することを仮定している。本論文では，こ の考え方に応力へのロール速度比の影響を追加すること で非等速ロールでの圧縮成形体重量の計算を行った。

非等速ロールに関して，既報[3]の等速ロールの場合と 同様に以下の (1) (4)の流れで粉体の圧縮成形体重量を計 算した。

(1) ロール壁面と粉体の間の「Slip region」の応力 $(\mathrm{d} \sigma / \mathrm{d} x)$ を求める。

(2) ロール壁面と粉体の間の「Nip region」の応力 $(\mathrm{d} \sigma / \mathrm{d} x)$ を求める。

(3) (1)と(2)の式より, 粉体の嚙み込みが始まる角度 (Nip angle）を求める。

(4) (3)で求めた Nip angleより, 圧縮成形体重量を算出 する。

これらの手順の詳細は次項にて説明する。

\section{1 非等速ロールでの Nip angle の算出}

\subsection{1「Slip region」での微小面積にかかる応力}

非等速ロール条件での Nip angle $\alpha$ の算出の際, Slip region に関してはロール速度の影響を受けないこと（CSL やWYL はロール速度によらず一定であること）を仮定 しているため, Johanson model と同じ式を用いる。導出 は以下となる。

壁面と粉体の間の摩擦は粉体同士の摩擦よりも小さい ことがほとんどであるため, 通常, 粉体の壁面摩擦角は 内部摩擦角よりも小さくなる。そのため, 限界状態線 (Critical state locus, CSL), 壁面崩壊線（Wall yield locus,

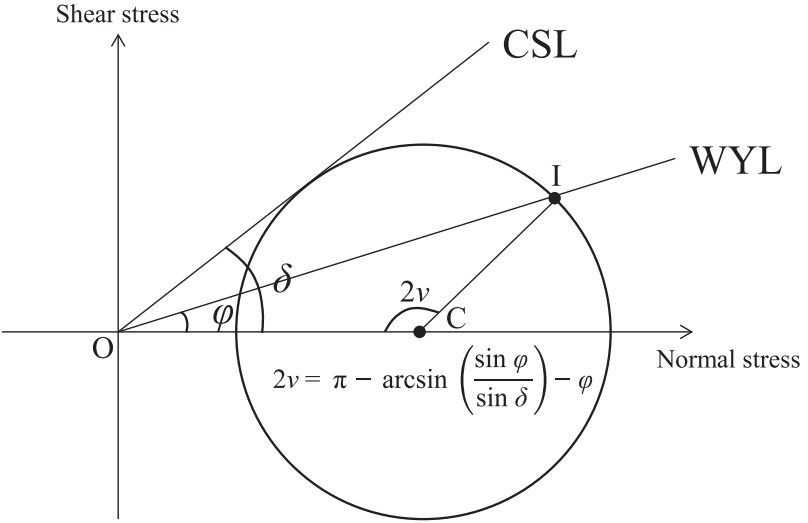

Fig. 3 Mohr stress circle diagram

WYL）とモール円の関係は Fig. 3 のようになる[3]。この 時, WYL とモール円との交点を I，モール円の中心を C とすると, 直線 $\mathrm{CI}$ と直線 $\mathrm{CO}$ の成す角 $2 v$ は, 以下の $\mathrm{Eq}$. (1)で表すことができる。

$$
2 v(\delta, \varphi)=\pi-\arcsin \left(\frac{\sin \varphi}{\sin \delta}\right)-\varphi
$$

ここで, $\delta$ は内部摩擦角， $\varphi$ は壁面摩擦角を表す。角度 は，モール円の定義より，壁面に接している粉体と主応 力面とのなす角度を意味する。

ここで，ロール間ギャップが最小の位置の角度を 0 と した時に, 角度 $\theta$ にあるロール上の任意の点での, ロー 儿壁面との接線と応力が最大となる面との成す角は以下 の Eq. (2) となる。

$$
\omega=\frac{\omega_{1}+\omega_{2}}{2} \pm\left(\frac{\pi}{4}-\frac{\delta}{2}\right)
$$

ここで, $\omega_{2}=v(\delta, \varphi), \omega_{1}=\pi / 2$ とおくと, 2 つの応力面と $x$ 軸との交点（点 $\mathrm{a}$ と点 $\mathrm{b}$ ）の 2 点間の距離を $\omega$ より計算 でき，以下の Eq. (3) となる。

$$
\begin{aligned}
& x_{\mathrm{b}}-x_{\mathrm{a}}=\frac{D}{2}\left[1+\frac{G}{D}-\cos \theta\right] \\
& \left\{\cot \left[\frac{\theta+v+\frac{\pi}{2}}{2}-\left(\frac{\pi}{4}-\frac{\delta}{2}\right)\right]-\cot \left[\frac{\theta+v+\frac{\pi}{2}}{2}+\left(\frac{\pi}{4}-\frac{\delta}{2}\right)\right]\right\}
\end{aligned}
$$

ここで， $D$ はロール直径， $G$ はロール間ギャップを表す。 また，この時の各点の応力は, $x$ に対する応力の伝わり 方が一定であると仮定すると，以下の Eq. (4) となる。

$$
\ln \sigma_{\mathrm{b}}-\ln \sigma_{\mathrm{a}}=4\left(\frac{\pi}{2}-\theta-v\right) \tan \delta
$$

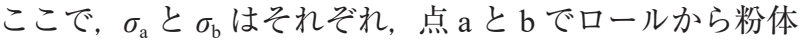
へ加わる応力を表す。一方, $\mathrm{d} \sigma / \mathrm{d} x$ に関しては以下の $\mathrm{Eq}$. (5)の関係が成り立つ。

$$
\frac{d \sigma}{d x}=\sigma \frac{d \ln \sigma}{d x} \approx \sigma \frac{\ln \sigma_{\mathrm{b}}-\ln \sigma_{\mathrm{a}}}{x_{\mathrm{b}}-x_{\mathrm{a}}}
$$

よって, Eq. (3)(4)(5) より, d $\sigma / \mathrm{d} x$ は以下の Eq. (6) で表す ことができる。 


$$
\begin{aligned}
& \frac{d \sigma}{d x}=\frac{4 \sigma_{\mathrm{C}}\left(\frac{\pi}{2}-\theta-v(\delta, \varphi)\right) \tan \delta}{\frac{D}{2}\left(1+\frac{G}{D}-\cos \theta\right)\left[\cot \left(\eta(\theta, \delta, \varphi)-\frac{\pi}{4}+\frac{\delta}{2}\right)-\right.} \\
& \left.\cot \left(\eta(\theta, \delta, \varphi)+\frac{\pi}{4}-\frac{\delta}{2}\right)\right] \\
& 2 \eta(\theta, \delta, \varphi)=\theta+v(\delta, \varphi)+\frac{\pi}{2}
\end{aligned}
$$

ここで， $\sigma_{\mathrm{C}}$ は粉体にロールから加わる応力を表し, Nip angleの計算の際は任意の定数とする。Nip region と Slip region で $\sigma_{\mathrm{C}}$ が同じであることを仮定して計算を行うた め， $\sigma_{\mathrm{C}}$ は任意の定数であるが Eq. (10) とは同じ值を用い る。CSL や WYL はせん断速度によらず一定と仮定して いるため, Eq. (6) を非等速ロールプロセスにも, そのま ま適用することとする。

\subsection{2「Nip region」での微小面積にかかる応力}

既報[8]にて，溶媒を含む粉体を 2 本の非等速ロールで 圧縮した際に，粉体が速度の速いロール側でより延伸さ れる形で，速度勾配を持って圧縮されることが DEM シ ミュレーションにより明らかとなっている。そこで本論 文でも，溶媒を含む粉体が速度勾配を持って圧縮される ことを想定し, Nip regionの式は, 以下を仮定して求める。

(i) A ロールより B ロールが速く, A ロール側と B ロー ル側の粉体の嚙み込み量の比は B ロールと A ロール の速度比 $r\left(=S_{\mathrm{B}} / S_{\mathrm{A}}\right)$ に等しくなる。つまり, B ロール 側で角度 $\theta$ で歯み込んでいる粉体は, A ロール側で $\theta / r$ の角度にいる粉体と同時に動くとする（Fig. 4）。

(ii) Nip angle $\alpha$ で歯み込んだ粉体はロールとともに移動

し， $\theta=0$ まで圧縮されながら移動する。

計算領域の微小範囲を $\Delta L$ とすると，任意の角度 $\theta$ で 噛み込む粉体体積 $V_{\theta}$ は微小台形（Fig. 4 の黑色部）に成 形幅を掛けた体積に等しくなるため, 成形幅 $H$ を用いて 以下の Eq. (7) で表せる。

$$
V_{\theta}=\frac{H}{2}\left(\frac{\Delta L}{r} \cos \frac{\theta}{r}+\Delta L \cos \theta\right)\left\{G+\frac{D}{2}\left(2-\cos \theta-\cos \frac{\theta}{r}\right)\right\}
$$

ここで， $\sigma_{\theta}, V_{\theta}$ はそれぞれ角度 $\theta$ における粉体へ加わる 応力と粉体の体積を表す。粉体を圧縮した際の応力 $\sigma_{\theta}$ と 体積 $V_{\theta}$ の間に以下の Eq. (8) の関係が成り立つことを仮 定する。

$$
\sigma_{\theta}=\sigma_{0}\left[\frac{V_{0}}{V_{\theta}}\right]^{K}
$$

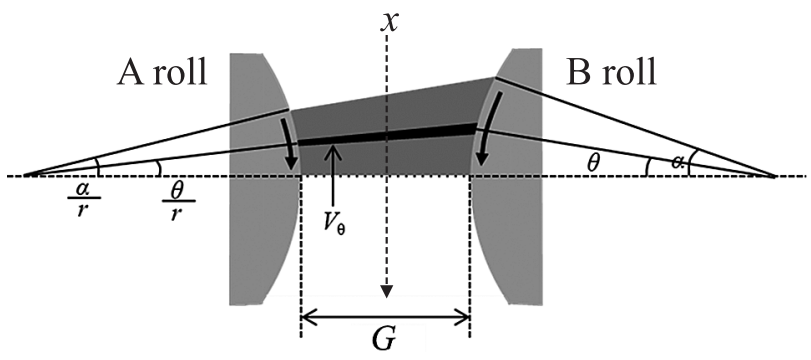

Fig. 4 Modified Johanson model assuming the velocity gradient of powders between $\mathrm{A}$ and $\mathrm{B}$ rolls
ここで， $\sigma_{0}, V_{0}$ はそれぞれ $\theta=0$ における応力と体積， $K$ は材料によって決まる圧縮係数である。Nip angleで噛み 込んだ粉体が任意の角度 $\theta$ に存在する時に粉体へ印加さ れる応力は, Eq. (7) と Eq. (8) より以下の Eq. (9) とにな る。

$$
\sigma_{\theta}=\sigma_{0}\left\{\frac{\frac{G}{r}+G}{\left(\frac{1}{r} \cos \frac{\theta}{r}+\cos \theta\right)\left[G+\frac{D}{2}\left(2-\cos \theta-\cos \frac{\theta}{r}\right)\right]}\right\}^{K}
$$

この式を $x\left(=-\frac{D}{2} \sin \theta\right)$ に関して微分すると以下の Eq. (10) のように表される。

$$
\begin{aligned}
& \frac{d \sigma}{d x}=\frac{K \sigma_{\mathrm{C}} E(D, r, G, \theta)}{\frac{D}{2} \cos \theta\left(\frac{1}{r} \cos \frac{\theta}{r}+\cos \theta\right)\left(G+\frac{D}{2}\left(2-\cos \theta-\cos \frac{\theta}{r}\right)\right)} \\
& E(D, r, G, \theta)= D \sin \theta \cos \theta \\
&+ \frac{D}{r^{2}} \sin \left(\frac{\theta}{r}\right) \cos \left(\frac{\theta}{r}\right)+\left(\frac{D}{2 r}+\frac{D}{2}\right) \\
&\left(\sin \theta \cos \left(\frac{\theta}{r}\right)+\frac{1}{r} \sin \left(\frac{\theta}{r}\right) \cos \theta\right) \\
&-(G+D) \sin \theta-\frac{1}{r}\left(\frac{G}{r}+\frac{D}{r}\right) \sin \frac{\theta}{r}
\end{aligned}
$$

ここで， $\sigma_{\mathrm{C}}$ は粉体にロールから加わる応力であり， Nip angle の計算の際は Eq. (6)の $\sigma_{\mathrm{C}}$ と同じ值を用いる。

\subsubsection{Nip angle $a$ の算出}

Eq. (6) と Eq. (10) の值の大小は, 「Slip region」と「Nip region」の安定性を決める。つまり, この交点の角度か ら粉の嚙み込みが始まると考えられるため, この角度を Nip angle $\alpha$ とする（Fig. 5)。Eq. (6) と Eq. (10)より， $\alpha$ は 成形プロセス条件 $(D$ ：ロール直径， $G$ : ロール間ギャッ プ, $r$ : ロール速度比) だけでなく, 粉体特性（ $\delta$ : 内部 摩擦角, $\varphi$ : 壁面摩擦角, $K$ : 圧縮係数) によっても決ま ることがわかる。

\subsection{Nip angle からの圧縮成形体重量の算出}

本計算では Nip angle で噛み込んだ粉体は, そのまま $\theta=0$ まで圧縮されながらロールとともに移動すると仮定 している。そのため, B ロールが $\Delta L$ 進んだ際に $\theta=0$ を 通過する圧縮成形体重量 $W_{\text {calc }}$ は Nip angle での嚙み込み 体積 $V_{\alpha}$ に比例すると考えられる（Fig. 6）。また，Nip angle での粉体の密度 $\rho$ がわかれば, 以下の Eq. (11)のよ

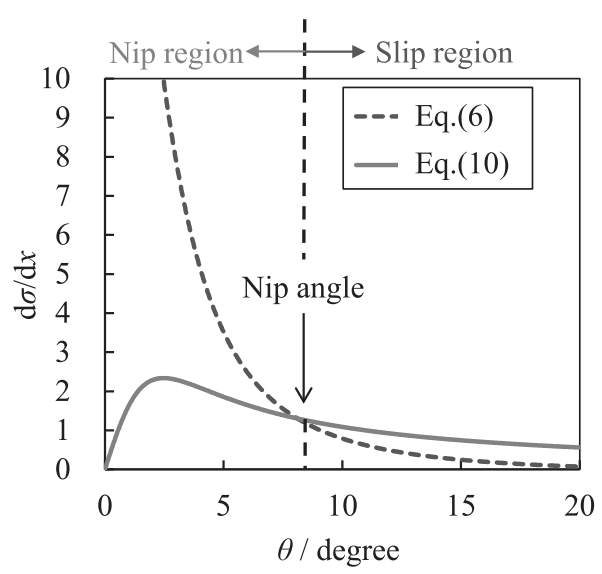

Fig. $5 \theta$ dependence of $\mathrm{d} \sigma / \mathrm{d} x$ 


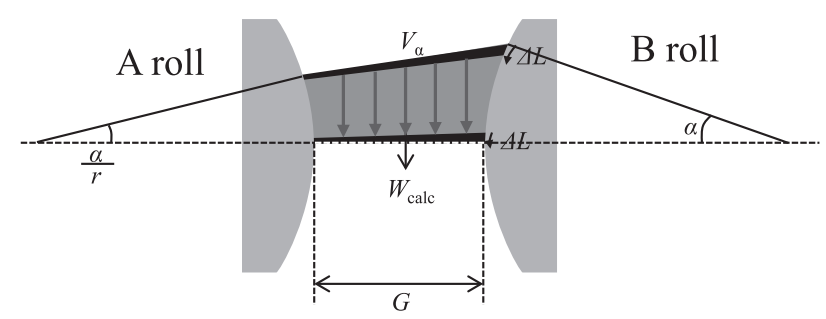

Fig. 6 Assumed powder volume change between $\theta=\alpha$ and $\theta=0$

うに全圧縮成形体重量 $W_{\text {total_calc }}$ を求めることができる。

$$
\begin{aligned}
W_{\text {total_calc }}= & \rho V_{\alpha} \\
= & \frac{\rho H}{2}\left(\frac{\Delta L}{r} \cos \frac{\alpha}{r}+\Delta L \cos \alpha\right) \\
& \left\{G+\frac{D}{2}\left(2-\cos \alpha-\cos \frac{\alpha}{r}\right)\right\}
\end{aligned}
$$

ここで, 単位面積あたりの圧縮成形体重量 $W_{\text {calc }}$ は $W_{\text {total_calc }}$ を圧縮成形体とロールの接触面積である $H \times \Delta L$ で規格化 し(割り), 以下の Eq. (12)で表す。

$$
W_{\text {calc }}=\frac{\rho}{2}\left(\frac{1}{r} \cos \frac{\alpha}{r}+\cos \alpha\right)\left\{G+\frac{D}{2}\left(2-\cos \alpha-\cos \frac{\alpha}{r}\right)\right\}
$$

本論文では $\rho$ はかさ密度と仮定して計算を行う。

\section{3. 実験方法}

\section{1 粉体試料の作製}

本論文では，モデル粉体としてシリカ粒子とポリエチ レングリコール（PEG）に水を加えて, 溶媒を含む粉体 を作製した。微粒子は粒子形状が球形で粒径分布が小さ いことからシリカ粒子を選択し, バインダーとしては水 中で高分子同士が凝集体を形成しない PEG を選択した。 シリカ粒子は株式会社日本触媒製シーホスターKE-P250 (粒径 $2.5 \mu \mathrm{m}$ ), PEG は富士フィルム和光純薬株式会社製 ポリエチレングリコール 20,000（分子量 20,000）を用い た。シリカ粒子と PEG と蒸留水をバーティカルグラニュ レーター（株式会社パウレック製VG-01）を用いて，擋 找羽根周速 $9 \mathrm{~m} / \mathrm{s}$, 時間 $30 \mathrm{~s}$ で摚拌して, 粉体試料を作 製した。また，粉体試料は固形分（シリカ粒子, PEG）
濃度が $75 \mathrm{wt} \%$ になるように調製した。シリカ粒子と PEG の重量比は 98:2 とした。

\section{2 ロール圧縮成形}

粉体試料を 2 本ロール圧縮成形機（ロール直径 $D=$ $150 \mathrm{~mm}$ ）を用いて成形した。2 本ロール成形の模式図を Fig. 7 に示す。A ロール速度を $S_{\mathrm{A}}, \mathrm{B}$ ロール速度を $S_{\mathrm{B}}$ とし, A-B ロール間ギャップを $G$ とする。本実験では， $S_{\mathrm{B}}=$ $1500 \mathrm{~mm} / \mathrm{min}, 800 \leq G<850 \mu \mathrm{m}$ に設定して, $S_{\mathrm{A}}$ のみを変化 させる実験と, A, B ロール速度を一定 $\left(S_{\mathrm{A}}=600 \mathrm{~mm} / \mathrm{min}\right.$, $\left.S_{\mathrm{B}}=1500 \mathrm{~mm} / \mathrm{min}\right)$ にして， $G$ を変化させる実験を行っ た。ここで, 各ロール速度は周速度を表す。圧縮成形体 重量に関しては, 圧縮成形体を $1 \mathrm{~cm}^{2}$ に打ち抜き, 重量 を測定し, 10 簓所の平均を求めた。

\section{3 せん断試験による粉体特性評価}

圧縮成形体重量の予測值を計算するために必要な粉体 特性を求めるために, 粉体試料のせん断特性と圧縮特性 を粉体層せん断試験装置（株式会社ナノシーズ製 NSS500）を用いて求めた。

粉体試料について, せん断試験により限界状態線 （CSL）と壁面崩壊線（WYL）を求め, そ㞦らの傾きか らそれぞれ内部摩擦角 $\delta$ と壁面摩擦角 $\varphi$ を求めた $[9,10]$ 。 壁面摩擦角に関しては粉体試料と, ロール表面と同じ表 面加工を行った SUS 基板との壁面摩擦角を求めた。セル は直径が $15 \mathrm{~mm}$ のものを用い, せん断速度は $10 \mu \mathrm{m} / \mathrm{s}$ で 行った。また, 垂直応力 $\sigma$ と粉体体積 $V$ との関係から圧 縮係数 $K$ を求めた。

以下に Fig. 8 を参照しながら, 粉体層せん断試験の手 順を述べる。ここで, 壁面摩擦測定は以下の粉体層せん 断試験においてセル下部を基板に変更して, 同様の方法 で行った。

（1）粉体試料をセルに詰め, 一番小さい垂直応力条件か ら順にせん断試験を開始した。荷重増加でせん断試 験を繰り返し, 垂直応力ーせん断応力の関係 (CSL) を求めた (Fig. 81)。

（2）測定点を線形近似し，その直線の傾きょり内部摩擦 角を求めた（Fig. 8(2)）。

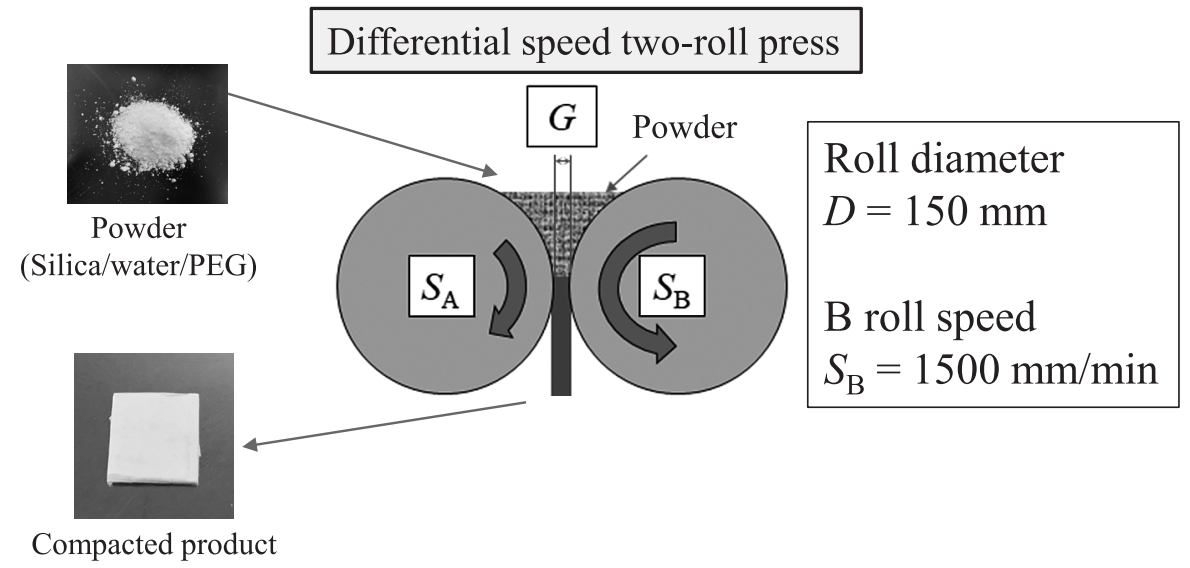

Fig. 7 Schematic illustration of two-roll press with differential speed 


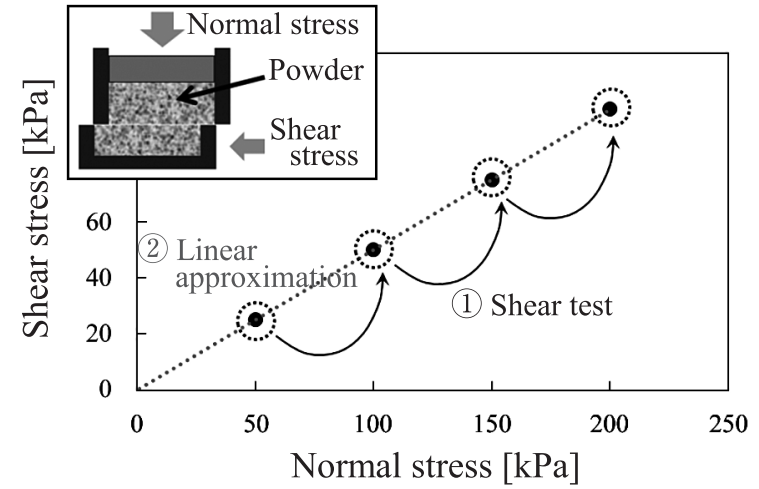

Fig. 8 Schematic overview of the shear test procedure

\section{4. 実験結果および考察}

粉体層せん断試験と壁面摩擦試験の結果を Fig.9(a)に 示す。粉体層せん断試験により CSL，壁面摩擦試験によ りWYLをそれぞれ求めた。CSLが WYLよりもせん断 応力が大きくなっているが, これは粉体間の摩擦が粉体壁面間の摩擦上りも大きいためと考えられる。また，圧 縮試験の結果を Fig. 9 (b) に示す。粉体試料の体積 $V$ と垂 直応力 $\sigma$ の対数が, 広い垂直応力範囲で線形関係を示し ていた。これは Eq. (3)の仮定が成り立っていることを意
味する。これらの結果より求まった内部摩擦角, 壁面摩 擦角々圧縮係数は，それぞれ $\delta=42.4 ， \varphi=23.7, K=31.5$ であり,これらの值を用いて以降の計算を行った。

A ロール速度 $S_{\mathrm{A}}$ を変化させた時の（ロール速度比 $r=$ $S_{\mathrm{B}} / S_{\mathrm{A}}$ を変化させた時の), 単位面積あたりの圧縮成形体 重量を測定した実測值と，上記の式を用いて算出した計 算値の比較を Fig. 10 (a) に示す。Fig. 10 (a) より, 計算値 は $S_{\mathrm{A}}$ が遅くなると，すなわち $r$ が大きくなると減少し た。本計算では, 速度の遅い $\mathrm{A}$ ロール側での粉体噛み込 み量が減少するため, 圧縮成形体重量が減少した。実測 值でも同様の傾向が見られて扮り, 計算によりロール速 度比依存性を表せていることがわかった。

次にロール間ギャップ $(G)$ を変化させた際の, 圧縮 成形体重量の計算値と害測值の比較を Fig. 10 (b) に示す。 計算値は, $G$ が大きくなると増加した。本計算では, ロー ル間ギャップが大きくなると粉体噛み込々量が増加する ため, 圧縮成形体重量が増加した。実測值でも同様の傾 向が見られており，本モデルにより実験の傾向が再現で きていることがわかった。

一方で, Fig. 10 に示したように, 絶対值は実測值が計 算值よりも大きくなっていた。この理由としては, ロー ル間の粉体の速度勾配の仮定が実際と異なることやロー ル間ギャップが実際は変化していることなどが考えられ る。また, 計算ではニップアングルでの粉体密度をかさ
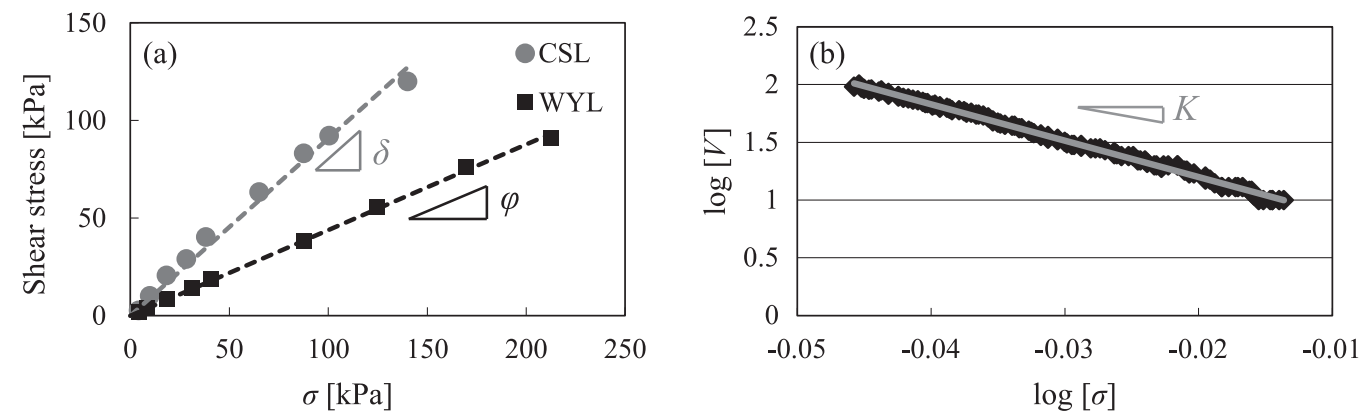

Fig. 9 (a) Measured CSL (circles) and WYL (squares), (b) results of compaction test
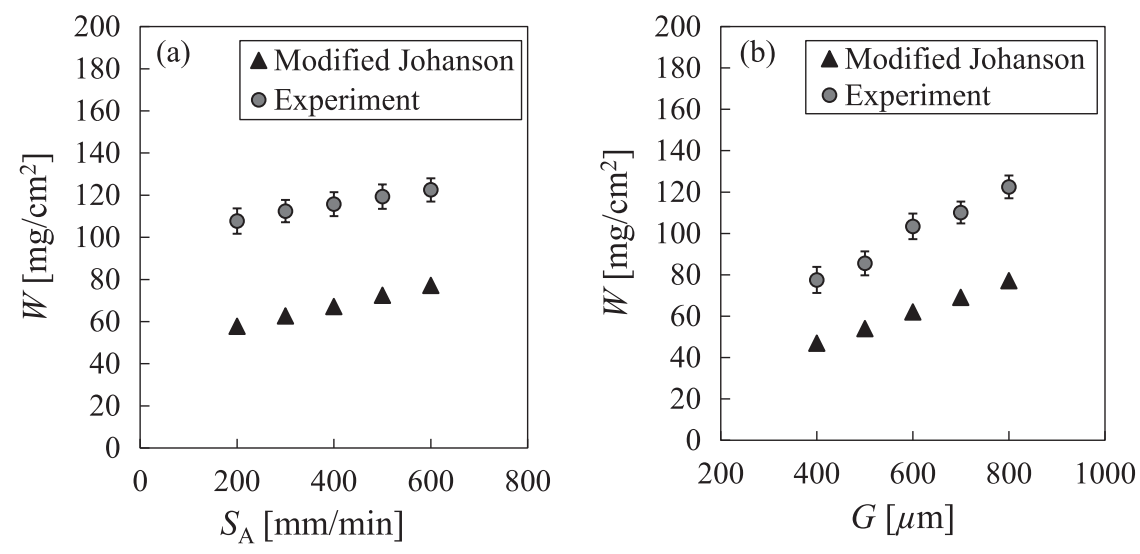

Fig. 10 (a) Roll speed $S_{\mathrm{A}}$ dependence and (b) roll gap $G$ dependence of the weight calculated by modified Johanson model and measured weight of the compacted product per unit area $W$ 
密度と仮定したが，実際はかさ密度よりも大きいと考え られ，このことも絶対值のずれに影響していると考えら れる。

\section{5. 結 言}

2 本のロール速度が異なるロール圧縮プロセスで粉体 を圧縮成形する場合について，速度勾配を考慮して補正 したJohanson モデルを提案し，実測值との比較を行うこ とでその妥当性を評価した。計算值と実測值はともに, 2 本のロール速度比 $r$ が大きくなると減少し， ロール間
ギャップが大きくなると増加した。計算值と実測值で傾 向は一致しており，本モデルの妥当性を確認することが できた。一方で，絶対值は実測值が計算值よりも大きく なっていた。この理由としては，ロール間の粉体の速度 勾配の仮定が実際と異なるためやロール間ギャップが実 際は変化していることなどが考えられる。また，計算で はニップアングルでの粉体密度をかさ密度と仮定したが, 実際はかさ密度よりも大きいと考えられ，このことも絶 対值のずれに影響していると考えられる。

\section{Nomenclature}

$D \quad$ : roll diameter

$S_{\mathrm{A}} \quad$ : peripheral speed of A roll

$S_{\mathrm{B}} \quad$ : peripheral speed of B roll

$r \quad$ : peripheral speed ratio of A roll and B roll $\left(S_{\mathrm{B}} / S_{\mathrm{A}}\right)$

$G \quad$ : roll gap

$\delta \quad:$ angle of internal friction

$\varphi \quad$ : angle of wall friction

$K$ : compressibility constant [mm] $\quad \sigma \quad:$ normal stress

$[\mathrm{mm} / \mathrm{min}] \quad \sigma_{\theta} \quad:$ normal stress at an angle of compaction position $\theta$

$[\mathrm{mm} / \mathrm{min}]$

$[\mathrm{mm} / \mathrm{min}]$

$V \quad:$ volume of powder

$[\mathrm{kPa}]$

$\theta \quad$ : angle of compaction position

$\left[\mathrm{cm}^{3}\right]$

$[\mu \mathrm{m}]$

$H \quad$ : compaction width

[degrees]

$[\mathrm{mm}]$

[degrees]

$L \quad$ : compaction length

[mm]

[degrees]

$W \quad$ : weight of compacted product per unit area

$\left[\mathrm{mg} / \mathrm{cm}^{2}\right]$

\section{References}

[1] P. Kleinebudde, Roll compaction/dry granulation: pharmaceutical applications, Eur. J. Pharm. Biopharm. 58 (2004) 317-326.

[2] S. C. Deevi, Powder processing of FeAl sheets by roll compaction, Intermetallics 8 (2000) 679-685.

[3] J. R. Johanson, A rolling theory for granular solids, J. Appl. Mech. 32 (1965) 842-848S.

[4] G. Bindhumadhavan, J. P. K. Seville, M. J. Adams, R. W. Greenwood, S. Fitzpatrick, Roll compaction of a pharmaceutical excipient: Experimental validation of rolling theory for granular solids, Chem. Eng. Sci. 60 (2005) 3891-3897.

[5] K. Odagi, T. Tanaka, Y. Tsuji, Compressive flow property of powder in roll-type presses - numerical simulation by discrete element method-", J. Soc. Powder Technol., Japan 38 (2001) 150-159.
[6] A. R. Muliadi, J. D. Litstera, C. R. Wassgrenb, Validation of 3-D finite element analysis for predicting the density distribution of roll compacted pharmaceutical powder, Powder Technol. 237 (2013) 386-399.

[7] Y. A. Yusof, A. C. Smith, B. J. Briscoe, Roll compaction of maize powder, Chem. Eng. Sci. 60 (2005) 3919-3931.

[8] M. Sakai, K. Takabatake, K. Tamura, K. Hatano, A. Minakuchi, Why do wet-particles adhere to a high-speed roll in a three-roll mill? Phys. Fluids 31 (2019) 033302.

[9] Y. Shimada, S. Hatano, S. Matsusaka, A new method for evaluating powder flowability using constant volume shear tester, J. Soc. Powder Technol., Japan 54 (2017) 90-96.

[10] JIS, Z8835, Direct shear testing method for Critical State Line (CSL) and Wall Yield Locus (WYL) of powder bed. 